\title{
IN WHOSE INTEREST? ANTE-BELLUM ABOLITIONISM, THE BIBLE, AND CONTEMPORARY CHRISTIAN ETHICS
}

\author{
MARION L. S. CARSON* \\ International Baptist Theological Study Centre, Amsterdam \& Scottish Baptist College, Paisley
}

\begin{abstract}
Christians look to Scripture to inform their ethical decision-making, believing that God speaks through it. However, disagreement as to what the Bible requires us to do can often lead to acrimonious splits within the church. So long as sharp divisions amongst Christians over ethical issues remain, injustices continue, and the reputation of the church is undermined. This article suggests that lessons may be learned from the story of the use of the Bible in the American Abolitionism debate which can help the contemporary church to discuss and perhaps even resolve some enduring ethical questions which are dividing Christians today.
\end{abstract}

KEY WORDS: biblical hermeneutics, slavery, abolitionism, Christian ethics

\section{Introduction}

For most, if not all Christians, it goes without saying that the Bible is the primary source for moral guidance in the church. Christian children are taught from an early age that the Bible is God's word and that it is to be obeyed, for in it truth is to be found. Indeed, Christians from all traditional backgrounds are agreed that Scripture is normative for living. It tells us of the basics of our faith, contains the earliest revelations of God's work in Christ Jesus and the earliest recorded theological and ethical reflections. Although views of how far Scripture should inform our everyday lives vary from tradition to tradition, Christians are agreed that God continues to speak through this book. As John Webster says, the Bible is

God's self-communication, that is the acts of Father, Son, and Spirit which establish and maintain that saving fellowship with humankind in which God makes himself known to us and by us (Webster 2003: 8).

MARION L. S. CARSON (PhD 1998, University of Glasgow) is Adjunct Supervisor at International Baptist Theological Study Centre, Amsterdam, Netherlands, and Adjunct Lecturer at Scottish Baptist College, Paisley, Scotland, United Kingdom. Email: marionlscarson@gmail.com. 
The problem is, however, that while there may be agreement that God communicates through the Bible, what that communication may consist of is often the subject of intense debate. Consequently, despite unanimity that we can look for guidance from Scripture, it has, in many instances, proven very difficult to reach consensus as to what that guidance might be. This is true with regard to matters of doctrine, practice and ethics. Despite centuries of Biblical study, both within and outside the Academy, we continue to disagree (amongst other things) on our understanding of the eucharist, of baptism, and of the place of the Holy Spirit, all the while asserting that we base our theological position on Scripture. While questions of doctrine tend to be restricted to rarefied theological circles, less likely to be the subject of discussion amongst ordinary people in the churches, the situation is rather different when it comes to ethical issues which affect believers in their everyday lives. For example, we disagree on questions of sexual behaviour, on matters of war and peace, of national identity, and the place of women in our churches. Very often, debate on these matters results in impasse, which leads either to division (often acrimonious) or an agreement to differ which means that the topic remains undiscussed and communities of believers continue to live lives in silent separation from one another. The upshot is not only disunity amongst believers, but the undermining of the reputation of the church. The Christian claim to be a people who seek justice and bring a message of love to the world becomes severely compromised.

How can we move forward in matters such as these? In this article, I will suggest that we may look to history to help us. How our predecessors used Scripture, their mis-steps and successes, may be able to help us avoid making mistakes in our own time. To this end, it is my intention to tell the story of the nineteenth-century American Abolitionist debate, in which Biblical interpretation played such a central and crucial role, and to use it as a test case for the use of the Bible in Christian ethical discussion. I will draw some lessons from it which I hope will be helpful for Christians today as they seek to formulate a Scripturally informed ethic on matters of justice both within church life itself and in the wider world. I will argue that the story teaches that it is crucial to develop self-awareness as readers, to recognise that it is possible to use the Bible to bolster our own views and agendas (rather than allow it to teach and transform us) and even to use it to oppress others. I will suggest that the Abolitionists' intuitive hermeneutic, which focussed on the message of love and redemption conveyed through Biblical narrative, metaphor and symbol and took the 'Golden Rule' as its central ethical principle, will serve us better than an approach to Scripture which seeks direct instruction on which we must act unquestioningly. I will suggest that those of us who want to live Biblically informed lives must, as we read and discuss, 
ask ourselves this question: whose interests we are seeking-our own, or God's?

\section{The Use of the Bible in the American Abolitionist Debate}

That slavery is morally unacceptable is taken as read by most, if not all, Christians today. Few if any, would take issue with the Article Four of the Universal Declaration of Human Rights which declares that 'No one shall be held in slavery or servitude; slavery and the slave trade shall be prohibited in all their forms'. As Kevin Bales says,

We do not have to win the moral argument against slavery; no government or organized interest group is pressing the case that slavery is desirable or even acceptable. No priest or minister is standing in the pulpit and giving biblical justifications for slavery. No philosophers offer up rationalisations for slavery (Bales 2007: 29f).

Furthermore, most if not all Christians are agreed that this view of slavery is entirely compatible with and, in fact, based on Biblical values. But this was not always the case. It took nearly eighteen hundred years for the Christian church to begin to question the moral status of slave-holding, and the subsequent struggle for Abolition was a painful and often violent one. In the United States in particular, early challenges to slavery amongst Quakers opened the way for a very acrimonious and divisive debate in which lives came to be at stake in the civil war (Kolchin 1993; Smith 1998). Before the anti-slavery campaign people thought that God's word sanctioned and even commanded the enslavement of others, but by the end, it was universally believed that this was not what the Bible taught at all (Meeks 1996; Carson 2016: 13-35). During the debate itself both pro-slavers and anti-slavery activists were convinced that the authority for their stance came from Holy Scripture itself. How did this change come about?

\section{The Quakers}

Prior to the beginning of the Abolitionist campaign in the 1670s, few people questioned the rights and wrongs of slavery. Slavery was simply the norm. Before then some isolated voices, mainly Catholic priests and missionaries, had issued a challenge against the status quo, but these voices were few (Rice 1964; Maxwell 1975). Eventually however, Quakers began to realise that the enslavement of others was incompatible with their principles of equality and non-violence (Durham 2010). They recognised that if they professed to hold to these principles, slave-holding could not be continued within their communities. It was self-evident that the slaves who were employed in the plantations and as domestic servants, even if they were treated fairly well, were not viewed as equals and were certainly not free. Rather 
they and their families were considered to be property whose lives were entirely at the disposal of their owners.

The first recorded written protest against slavery in North America comes from 1688 when the Germantown Pennsylvania congregation of Mennonite Quakers wrote to their monthly meeting: 'There is a saying, that we should do to all men like as we will be done ourselves; making no difference of what generation, descent or colour they are' (Morgan 2005: 37).

So it was that the campaign against slavery within the Quaker community began. Slavery was profitable, however, and since many Quakers were themselves slave-holders, change was slow in coming. Nevertheless, despite opposition within their own ranks, a change of heart gradually developed, and the incompatibility of slave-holding with their way of life came to a central tenet of Quaker thinking. In 1758, the Philadelphia Yearly Meeting took the decision that slaveholders should be disowned. Rumours in Europe that American Quakers 'handel men as they handel there cattle' were deemed shameful; something needed to be done about it. Throughout the Quaker campaign the appeal to the Golden Rule (or 'law of love' Matthew 7:12) was central-we would not wish to be enslaved ourselves, so we must not enslave others.

The anti-slavery message spread beyond the Quaker world. In particular, the writings of John Woolman and Anthony Benezet were highly influential at an international level, playing a major role in the development of anti-slavery thinking amongst British Quakers, William Wilberforce's 'Clapham Sect', and ultimately in the abolition of slavery act there (Davis 1970: 319-62; Frost 1980). Benezet's pamphlet of 1760 Observations on the Inslaving, Importing and Purchasing of Negroes reminded its readers of the command to love God and one another. Slavery could not be consistent with the Gospel. In his 1785 work, A Caution to Great Britain, he emphasised equality between white and black people, calling the latter 'our fellow-creatures, as free as ourselves by nature', and he warned of divine judgement against those who enslaved them.

\section{Pro-slavers}

Anti-slavery thinking became increasingly influential, particularly in the Northern states. Legislation was introduced which banned the import of slaves, and the number of those enslaved began to reduce. However, inevitably opposition arose, not least from slave-owners. And just as the Quakers had given Scriptural grounds for their change of heart, so too their opponents appealed to the Bible as they made their case. They did so by focussing on two major themes-social order and race. It was commonly argued that slavery was ordained by God, and that through it, orderly society was to be maintained. The fact that Abraham ruled over a household of many 
male and female servants (Genesis 20:14) demonstrated that God's blessing was on him and his family. The same could be said for Jacob, who, when he became rich, became the owner of many slaves (Genesis 30:43). Examples such as these were taken as providing a 'model for church and state' (FoxGenovese and Genovese 2005: 507). America's prosperity could be put down to maintaining this Biblical practice of slave-holding, and it followed that changing this would not only put societal order at risk but would be to go against God's will.

A second major argument held that it was God's intention that the negro race should be enslaved. The story of the curse of Ham was central to this argument. Noah, having been discovered drunk and naked by Ham, pronounces a curse on his son: 'Cursed be Canaan: lowest of slaves shall he be to his brothers' (Genesis 9:10). The commonly held view at the time was that Canaan referred to Africa. Therefore, the cursing of Canaan must apply to all black people (despite the fact that nowhere in Scripture is it said that Ham was black), and so their enslavement could be explained. Other arguments held that the enslavement of black people was actually part of God's plan for their welfare and betterment. Slave-holders could see themselves as taking people out of the degraded way of life in Africa, and offering them the opportunity to become Christians. In fact, it was argued that the Bible actually commanded slave-holding. Rev Fred Ross, for example, writing in 1857, referred to Leviticus 25:44-46, which says that slaves may be acquired from the surrounding nations and treated as property, and argued that this gave divine sanction to slavery (Ross 1969: 147). American slaveholders were merely doing God's will. However, as the argument on the basis of the Golden Rule gained ground, it became necessary to contend that things were not as straightforward as the anti-slavery people wanted to make out. The Golden Rule should be subject to proper interpretation. In a public letter to Rev Albert Barnes, Ross argued that 'Christ, in his rule'

presupposes that the man to whom he gives it knows, and from the Bible, (or providence, or natural conscience, so far as in harmony with the Bible,) the various relations in which God has placed him; and the respective duties in those relations; i.e. The rule assumes that he KNOWS what he OUGHT to expect or desire in similar circumstances (Ross 1969: 162).

That is to say, the Golden Rule should be seen through the lens of the social order which God has ordained, such as slavery, marriage and family life, and not the other way around. The Roman Catholic Bishop Kenrick of Philadelphia, in a preface to his translation of Paul's letter to Philemon, warned that 'the Gospel is not directed to disturb the actual order of society by teaching men to disregard their obligations, however severe their enforcement may appear' (Kenrick 1981: 32). If the appeal to the command to 
love your neighbour as yourself meant upsetting or changing that social order, then it must be considered highly suspect.

\section{Intellectuals}

While Quakers and an increasing number of other Abolitionists argued with the slaveholders, with clergy also taking sides, it was inevitable that academics should become involved in the debate. Most prominent amongst these was Charles Hodge, Professor of Systematic Theology at the Presbyterian Theological Seminary in Princeton. In the highly influential and widely read journal The Biblical Repertory and Princeton Review Hodge, who would later become Principal of the seminary, assumed Scripture to be the basis for any discussion of the rights and wrongs of slavery. Hodge was uneasy about slave-holding and believed that educating slaves and improving their family lives should eventually led to their emancipation, which would be wholly in line with the divine will. He could not, however, assent to Abolitionism. The problem was that neither Jesus nor Paul commanded the ending of slavery. Therefore, to abolish slavery would be a sin and the status quo must be maintained. He also argued that slaves should obey their masters, because the Bible told them to. In his essay The Fugitive Slave Law Charles Hodge wrote thus:

The obedience which slaves owe their masters, children, their parent, wives their husband, people their rulers, is always made to rest on the divine will as its ultimate foundation. It is part of the service which we owe to God... In appealing therefore to the Bible in support of the doctrine here advanced, we are not, on the one hand, appealing to an arbitrary standard, a mere statute book... but we are appealing to the infinite intelligence of a personal God, whose will, because of his infinite excellence, is necessarily the ultimate ground and rule of all moral obligation (Elliott 1860: 815).

The Bible was clear-it was God's will that slaves should obey their masters. They should not, therefore, rebel or try to escape, but see their situation as the result of the 'Infinite excellence' of the will of God for them.

If Hodge found himself conflicted about how to end slavery, others took a much more straightforward view. The Philadelphian Presbyterian minister Albert Barnes believed that ethos should always trump law. Thus, he argued that while it was true that Jesus did not actually demand the abolition of slavery, Christians should follow the principles of Christ's teaching. If they did this, he believed, it would be seen that the Bible did actually teach 'universal abolition' (Barnes 1857). Horace Bushnell, a Congregationalist minister in Connecticut, was similarly suspicious of the law-based approach. There was, he believed, a 'principle of virtue' in Scripture, and God speaks to his people through poetry and metaphor (Torbett 2006: 121,130). 
Readers could discover God's will through narrative and symbol and not simply through rule and statute.

The debate amongst academics and clergy did little or nothing to alleviate the suffering of millions of slaves or to move the practical argument forward. There was a deep hermeneutical divide and the debate became polarized-each side appealing to the same text but from a completely different standpoint. Some opted out of the debate altogether. That the pro-slavers could find support for their stance on the basis of the Bible so horrified the Abolitionist Lloyd Garrison that he jettisoned it completely. However, as Mark Noll points out, the Bible was too important in the minds of most Americans to be ignored in this way (Noll 2006: 32). And in a certain sense this view of Scripture ultimately played into the slave-holders' hands as they could prove to some that the anti-slavery stance was unbiblical and therefore unchristian.

Eventually, the impasse was overcome, not by clergy or academics but by a novelist. Harriet Beecher Stowe's sentimentalist novel, Uncle Tom's Cabin, sold 300,000 copies in the United States and many more abroad (Stowe 1995). Stowe's book told the story of a slave-Uncle Tom-and his experiences under various owners. It highlighted the suffering of slaves, in particular the separation of families at the whim of their owners. Tom is depicted as a sincere Christian, whose integrity and righteousness is contrasted with the wickedness of many slave-holders, in particular his cruel owner Simon Legree. In one scene, Tom is travelling on a steamboat down the Mississippi on his way to work for new owners. Two passengers, one a 'grave looking' clergyman and the other a young man who is described as having 'a face expressive of great feeling and intelligence', are discussing what the Bible has to say about slavery. The clergyman pronounces:

It's undoubtedly the intention of Providence that the African race should be servants-kept in a low condition. Cursed be Canaan; a servant of servants shall he be, the Scripture says.

The young man counters this with:

All things whatsoever ye would that men should do unto you, do you even so unto them. I suppose, he added, that is Scripture, as much as 'Cursed be Canaan' (Stowe 1995: 115-16).

It is quite clear with whom Beecher Stowe sides - the clergyman is missing the point of the gospel while the young man has grasped its significance. And her message is clear-those who use the Bible to justify the subjugation and enslavement of one race over another are looking after their own interests rather than being obedient to Christ's commands. Her highly successful 
novel enabled this message to be taken throughout the English-speaking world, and by the time the civil war broke out, the view that the Bible could be seen as supporting slavery was under deep suspicion if not already dead in the water.

\section{Slaves}

While slaves were not encouraged to learn to read and write, their owners did often seek to educate them in Christianity. Many owners saw it as their duty to 'civilise' and convert their slaves, and they educated them in the Scriptures as part of this process. Slaves were taught the major Biblical narratives and moral instruction. Most important was that slaves should know the Biblical understanding of their relationship with their masters. Thus, it was also commonly taught on the basis of New Testament parenesis, that slaves should accept their station in life and obey God and their masters. 'Slaves, obey your earthly masters in everything, not only while being watched and in order to please them, but wholeheartedly, fearing the Lord' (Ephesians 6:5-9; Colossians 3:22, 4:1).

It was important that slaves should not only be obedient but grateful for their God-given position. They should work for their masters 'as for the Lord'. An example of slave education along these lines is a catechism, which slaves were taught to recite, and which was written by Elias Neau for the Anglican Society for the Propagation of the Gospel in Foreign Parts in 1704 (Callahan 2006: 31-32).

'Who gave you a master and a mistress?'

'God gave them to me.'

'Who says that you must obey them?'

'God says that I must.'

'What book tells you these things?'

'The Bible.'

Quite clearly the purpose of this was to ensure that the slaves would not only obey their masters but remain faithful and not rebel against them. Despite efforts such as these, however, slaves developed quite a different understanding of what the Bible had to say (Saillant 2000). Most slaves were illiterate, and kept that way by their masters. However, when they listened to Scripture being read they heard a message of freedom from oppression and slavery. They learned of a God of mercy and compassion who created all people equal. The Joseph story gave hope for those sold into slavery and the gospel message of love and redemption spoke to them of Christ who came to set the captives free.

Above all, the Exodus narrative provided obvious parallels to their own situation. In a letter to Rev Samson Occom in 1774, Phillis Wheatley, a slave 
who became a published poet, wrote that 'Love of Freedom' must be a universal human trait, for 'otherwise, perhaps, the Israelites had been less solicitous for their Freedom from Egyptian slavery' (Carretta 2004: 69). Slaves came to see their owners as 'modern Egyptians' and themselves as the Israelites who must escape their oppressors: a just God would surely ensure the release of his people. As the spiritual song said, God's command to their owners was to 'let my people go'. Of course, thriving escape movements such as Harriet Tubman's underground railway took strength from the story seeing their leaders as modern-day Moses figures. For example, in 1800, in Henrico county Virginia, two enslaved brothers, Gabriel and Martin, preached that the Israelites were 'a type of successful resistance to tyranny; and it was argued, that now, as then, God would stretch forth his arm to save, and would strengthen a hundred to overthrow a thousand' (Harding 1997: 112).

Thus, slaves came to quite different conclusions from their owners as to what the Bible had to say about their situation. In time, too, educated slaves wrote about their experiences at the hands of their white owners and as they did so they often reflected theologically on what had happened. In his Interesting Narrative, Oloudah Equiano relates a conversation he had with a slave:

One day he said to me, very movingly, 'Sometimes when a white man take away my fish, I go to my master, and he get me my right; and when my master, by strength, take away my fishes, what me must do? I can't go to anybody to be righted'; then, said the poor man, looking up above, 'I must look up to God Mighty in the top for right.' This artless tale moved me much, and I could not help feeling the just cause Moses had in redressing his brother against the Egyptian (Equiano 2003: 110).

Cuobna Ottobah Cuguano, who had been brought by his owner to England in 1772, as he thought of the Joseph narrative with its parallel to his own experience, could see that something evil had been used by God for good (Genesis 50:20), but he was also fully aware of the ability of some to back up their pro-slavery by 'inconsistent and diabolical use of the sacred writings' (Cuguano 1787, in Carretta 2004: 156). Frederick Douglass, whose story was so influential in Britain and elsewhere, drew on the concept of the image of God to argue for the equal status of the enslaved.

The slave is a man, 'the image of God', but a 'little lower than the angels'; possessing a soul, eternal and indestructible; capable of endless happiness, or immeasurable woe... The first work of slavery is to mar and deface those characteristics of its victims which distinguish men from things and persons from property (Ruston 2004: 269). 


\section{Influences on Anti-Slavery Thinking - the Rise of Abolitionist Thinking amongst Christians}

It took a couple of hundred years for deeply entrenched views to change and the Quaker view of slavery to become the accepted norm. The Northern States won the war and the way to Abolition was made clear. President Lincoln signed the Emancipation Declaration which came into effect on 1 January 1863, and in 1865 the $13^{\text {th }}$ Amendment to the Constitution banned slavery altogether. So it was that an injustice which had caused extreme suffering to millions of people was brought to an end. The practice of slavery, which so many had considered to be in accordance with the will of God, was now seen to be as an evil which had to be eradicated. Not only that, the view that the Bible supported and even commanded that people should be enslaved and some should be their owners, was now completely overturned. In order to understand how this change of thinking came about, and to help us to draw lessons from it, in this next section we will consider the influences on and hermeneutical approach of each group in greater detail. How did they come to have the views that they did, and how did these ideas affect how they read the Scriptures?

The idea that slavery was wrong-headed did not begin with the Quakers. European intellectuals had been paving the way for Abolitionist thinking for some time (Anstey 1975). In 1576 the French philosopher Jean Bodin had written that slavery was unnatural, socially dangerous and cruel. In 1748, Montesquieu declared that that all human beings are born equal and in 1764 Voltaire denounced slavery as a 'degradation of the species'. The view of the British philosopher John Locke that each individual has inalienable rights over his or her own life was increasingly influential.

In 1791, Thomas Paine, who was a founding member of the American anti-slavery society, published his famous treatise, Rights of Man. In it he argued for the separation of church and state, against hereditary government, for free speech and the natural equality of mankind. Intellectual ideas such as these created an atmosphere in which movements such as the Quakers could develop and flourish (Anstey 1975). Quakers in Britain had generally been less educated than members of mainstream churches, and indeed were for a time banned from university education. They rebelled against mainstream religion, and were subject to oppression and even persecution. So it was that many emigrated to America in order to escape oppression and to practise freedom of religion. Given this background, it was, to a certain extent, natural that they should be the ones first to see the discrepancy between the principles which they professed to uphold and the way they were living, and that the first movement against slavery should arise within their ranks. 
These ideas also affected their view of the Bible. They believed that anyone who had the 'light within' (and this was available to all) could interpret Scripture. They emphasised the role of the Spirit in the life of the individual and the community, and deemed an educated clergy unnecessary. It comes as no surprise to learn that they were suspected of undermining the authority of the Bible. Quakers saw Scripture through the hermeneutical lens of the principles of freedom and equality by which their community defined itself. They were forced to conclude that to enslave others was in direct violation of these principles. An empathic realisation that they would not like to be enslaved in this way led them to see that slavery must be incompatible with the law which summed up all others.

As the experiences of slaves came to be more in the public eye, and as people became more aware of the suffering of slaves, the Abolitionist movement grew. For example, Theodore D. Weld's Slavery as It Is: Testimony of a Thousand Witnesses which contained evidence of torture and cruel punishments meted out to slaves, which was taken from reports by slaveholders to Southern newspapers, was published in 1839 (Thomas 1965: 57-62). It sold 22,000 copies within four months of publication, and was instrumental in Harriet Beecher Stowe joining the campaign.

Intellectuals who took up the cause were also increasingly influenced by ideas from Romanticism which were coming over the Atlantic. Writers such as Coleridge, who understood the Bible to be designed for the "moral and spiritual Education of the Human Race', looked to it to help them to understand deeper reality and humanity (Davidson 2009: 416). They relished the Bible's symbolism and imagery, spirituality and mystery, and saw it as a treasure trove of narrative, metaphor, symbolism, and poetry from which they could learn to understand human experience. The ideals of individualism, democracy, and human sympathy which Romanticism championed were popularised in Sentimentalist novels such as Beecher Stowe's Uncle Tom's Cabin.

Slaves themselves developed an experiential type of religion quite different from the Christianity their masters taught them. They knew that they were suffering great injustice, and the more they learned of Scripture the more they saw that their treatment at the hands of their owners was at odds with its teaching of a loving and just God. Their background of oral tradition led them to focus on Biblical narratives which spoke to them of freedom and justice, and themes of love and redemption. Theirs was an intuitive hermeneutic which was primarily based on their own experience of oppression and cruelty (Raboteau 2004: 239ff).

When the ideas of the Quakers gained ground, the interests of the people who owned slaves came to be under threat, and they had to defend their position. The Bible's acceptance of slavery gave them exactly the kind 
of backing they required. Yet it would be naïve and even unfair to accuse them all of being driven purely by greed. Many sincere Christians really believed that they were acting according to God's will, and that slaveholding was Biblically sanctioned. Those from a Puritan tradition and background believed that they had been given the land, their slaves and their prosperous way of life, by God himself. Slaves should be introduced to right religion, just as Israel's slaves were when they were circumcised. For Thornton Stringfellow, ending slavery would be against the constitution (the 'only National constitution which ever emanated directly from God') and would amount to 'moral hatred' of the laws of God (Elliott 1860: 45991).

Their hermeneutic was one of the 'plain meaning of the text' which could provide them with rules and statues for living, and they saw the more literary view of the Bible by intellectuals influenced by the Romantics as disingenuous sophistry which was disrespectful of the Word of God. But they too were influenced by ideas, not least the idea of their divine right to the new country. Popular ideas such as the theory of polygenesis, a theory in biology which argued for the hierarchy of races, influenced their understanding of the status of black people. Further, while Quakers tended to eschew theological education, Protestant mainstream churches placed high value upon it, and many seminaries grew up for the training of clergy. Intellectual leaders such as the theologians at Princeton who provided this education were deeply influenced by ideas which were coming from Europe. Reason as a way to understand the world, rather than superstition and speculation, was appealing to those of puritan heritage and was rapidly gaining ground (Reventlow 1984: 93-184). Following the Scottish 'common sense' philosopher Thomas Reid, the Princetonians emphasised the importance of sense experience, while allowing for some innate or intuitive knowledge (Noll 1983:13). Therefore, while they did allow for some idea of mystery, they were influenced by the idea that by collecting data and classifying evidence, humanity could learn all that there was to know.

The Princetonians were deeply suspicious of the ideas of Romanticism. They were prepared to say that Scripture was the mysterious 'word of God', but their hermeneutic approach was to treat it as a text-book of data for living. Newtonian law described the world, the Bible contained truth (Noll 1983: 39). German universities in particular began to eschew the notion of the supernatural in the study of the Bible, and historical-critical methods became increasingly influential. So when scholars such as Hodge sought guidance from Scripture as to how to respond to slavery, they treated the Bible like an instruction manual. The lack of overt support for Abolitionism in the Bible meant that they could not endorse it. 


\section{Lessons from History}

What lessons can be learned from the story of the Bible and Abolitionism in America? First, it is important for those who wish to find moral guidance in Scripture to be aware of the ideas which are influencing them as they read. Philosophical hermeneutics has long noted that our cultural, political and theological presuppositions and aspirations have a great deal to do with how we interpret Scripture (Thiselton 2009). While it may be tempting to think that our reading can be wholly objective, the story of the Abolitionist debate offers stark warning against falling into this trap.

As we have seen, slaves came to the Bible from a background of oral tradition, and found truth in Biblical narrative rather than the legal passages which were so important to their masters. The Princetonian scholars were strongly influenced by the enlightenment ideas coming from Europe, and made it central to the task of Biblical interpretation to find data and moral instruction. Harriet Beecher Stowe, on the other hand, would not have been able to write Uncle Tom's Cabin had the ideas of Romanticism not come from across the Atlantic, and the Quakers would not have been in existence at all had not ideas of freedom and equality been permeating the intellectual atmosphere for some time.

Cultural influences also played a crucial role. At the beginning of the struggle, a world without slavery was simply unthinkable, and it was taken for granted that Scripture endorsed the practice. The Quakers' challenge was profoundly counter-cultural and led to a long struggle even within their own ranks. Nevertheless, by the end, it was clear to all that the cultural acceptance of slavery had rested on a misunderstanding of the central message of the Bible.

Second, it is important not to divorce our Bible reading from the real experience of people. What can seem cut and dried from the point of view of the 'plain meaning of the text', from the perspective of the tradition to which we belong, or even within the quietness of the study, can and should be open to challenge through involvement in the real lives of those whose lives are impacted by the teaching of the church. It is instructive that while it seemed self-evident at the beginning of the campaign that slaveholding was coherent with the will of God, one of the greatest challenges to the commonly held view came from personal and eyewitness accounts of the suffering of those who lived as slaves.

Third, we need to be aware of our own personal interests and motivations as we read Scripture. Are we seeking to maintain the status quo, or to affect change? Either way, what is our motivation in the argument? Is it, for example, to please the people in our communities, or to keep ourselves in power, or to ensure that others do not get into power? In fact, our motivations are very likely to be mixed. While the Princetonian scholars knew that 
the debate over slavery was crucial in American society, their main concern was not the abolition or otherwise of slavery, but the protection of the idea of the inerrant word of God and Calvinistic worldview (Noll 1983: 13). Some historians believe that Quaker anti-slavery was not born out of a sense of love and altruism, arguing that they may have been more interested in keeping themselves pure with regard to their principles than with the wellbeing of black enslaved people. In each case, social and cultural interests played a large part in their decisions concerning their use of Scripture in the debate (Soderlund 1985: 177).

We need, therefore, to be self-aware as readers of Scripture-cognisant of the cultural, intellectual and social forces which are bearing down on us as we read. In particular, the Christian community to which we belong-its group values, reading traditions and hermeneutical stance-will be profoundly influential on us. We need to ask ourselves: are these influences and pressures clouding our judgement? Are they becoming more important to us than the desire to be faithful followers of Christ?

Lastly, contemporary readers of Scripture need to be aware that this is possible to use the Bible in an oppressive and coercive way, and to be alert to when this is being done (Fiorenza 1999). As we have seen, slaveholders used Scripture to ensure obedience and discourage rebellion amongst their slaves. To go against their masters was to go against God himself. It is very tempting to use the Bible to get our own way, in order to ensure that others do what we want. The lesson of the story of the Abolitionist debate must surely be that Christians should be aware of these risks and seek to avoid repeating the same mistakes. We can learn that blinkered, self-interested readings of Scripture can lead to oppression and cruelty towards others. This must surely make us want to avoid behaving in this way again. The question is, how can we do so?

\section{A Hermeneutic for Moral Guidance}

As the traditional view came under fire, the question confronting Christians became clear. Did the Bible support slavery or not? As we have seen, the primary approach of the pro-slavers was to treat the Bible as a rule book to be obeyed implicitly. On the other hand, the approach of the anti-slavery side was primarily to look at the bigger picture of Scripture, listening to the great narratives of Joseph, the Exodus and the gospel story itself, and hearing the message of love and redemption. For practical application, these themes were distilled into the principle of the Golden Rule which, according to Jesus' teaching, summed up the law and the prophets. As they read other references to slavery in the Bible through this lens, it became evident that the enslavement of others was far from congruent with the will of God. 
The pro-slavers' approach ultimately failed to provide a Biblical ethic on slavery. It was easy to cite chapter and verse in favour of slavery, but impossible to reconcile the injustice and suffering which it entails with the central narrative of God's redemptive love. The notion that some could become the property of others simply could not equate with the message of God's love for all his people. The Abolitionists' approach, on the other hand, has much to teach us. As the slaves and Quakers seem to have understood intuitively, the Bible is not merely a book of rules, it is also primarily a rich source of narratives and wisdom. Above all it is the story of God's intervention in history which has at its heart the desire to redeem his people from their captivity to sin. The 'redemptive impulse' which pervades Scripture brings along with it a principle of freedom and love which must form the heart of any Christian ethic.

Thus, a major lesson from the Abolitonists' use of Scripture is that where there are conflicting views amongst believers as to how to interpret Scripture in matter of ethics and justice, Jesus' words that the law of love fulfils all that the law prescribes should be central to our ethic. Is the view we are taking congruent with what we know of God's love in Scripture? Are we treating other as we would wish to be treated ourselves, or are we adopting double standards? Where we are puzzled by conflicting Biblical voices (voices which reflect the evolving and developing understanding of what it means to be the people of God) on ethical matters (Brueggemann 1997), we can have recourse to the law of love. This will not only provide a check on the temptation of seeking our interest rather than those of others, it will also help avoid a proof-texting mentality which is not only hard to gainsay but also runs the risk of silencing the compassion and empathy which is at the heart of the Biblical ethos.

\section{Conclusion}

Many of the ethical disagreements which face the church today threaten to divide Christians, just as the Abolitionist question did in the nineteenth century. In this essay, I have traced the story of the place of the Bible in the Abolitionist debate in America, using it as a test case for the use of the Bible in ethical discussion and decision-making. A literalist, proof-texting approach to Scripture which viewed the Bible as a book of rules whose "plain meaning' should be followed unquestioningly, failed ultimately to bring about true Christian social justice. Instead, a more intuitive hermeneutic which viewed the canon of Scripture as a whole and found an ethos of love and redemption within its narratives and meta-narrative was far more effective in moving towards the elimination of injustice and suffering.

The message of the story is clear-when it comes to resolving matters of ethics, a Biblical hermeneutic which looks for prescription, and bases itself 
on unquestioning obedience to rules and the 'plain meaning of the text', is inadequate and may even be counter-productive. It warns us against a reductionist view of Scripture which robs it of its richness and ultimately of its transformative power. For, as the Abolitionists and even uneducated slaves realised (while many clergy and scholars did not) the Bible is so much more than a book of rules and historical, doctrinal and moral data. Of course, this does not mean that we should disregard the moral and legal passages of Scripture altogether. Passages such as the Decalogue will always rightly be considered central to the Christian life. But to reduce the Bible to the status of a rule book is ultimately to miss the point. And the point, when it comes to matters of law and justice, as Jesus himself taught, and as the first Quaker Abolitionists realised, may be summed up in what we have traditionally referred to as the 'Golden Rule': 'Whatever you wish that others would do to you, do also to them, for this is the Law and the Prophets' (Matthew 7:12).

Today it is taken as read that slavery is contrary to the will of God. With regard to our ethical decision-making, however, if we learn anything at all from the place of Scripture in the American Abolitionist debate, it is that we ignore questions of hermeneutics, in our churches and at all levels of Christian education, at our peril. Christians continue, on the whole, to approach Scripture as if it were a book of data rather than the marvellous story of God's dealings with humanity. Most, if asked what the Bible has to say on any particular ethical matter, are likely to look for chapter and verse to provide an answer. The debate amongst academics and clergy during the Abolitionist debate illustrates just how crucial the question of Biblical interpretation was to the discussion. The Princeton academics adopted a literalist view which looked for direct instruction. For clergy like Bushnell and Albert Barnes, on the other hand, the aim was to look for ethos and principles by which to live, which they found expressed in the narrative, symbolism and metaphor in which the Biblical literature abounds. These two approaches brought about very different conclusions with regard to the teaching of the Bible on slavery. And ultimately, the words of Paul were proved true-'the letter kills and the Spirit gives life' (2 Corinthians 3:6).

Lastly, if we wish to be faithful 'people of the book' we must be self-aware readers who know well how easy it is to misunderstand and misappropriate Scripture's message, and to use it for our own purposes. This is true particularly when our own dearly held views are under threat, or when we want to influence or control the behaviour of others. We owe it to ourselves and others, to the church and to God himself, to learn to recognise the cultural and traditional influences which have a bearing on how we read Scripture, to acknowledge the possibility that we might be confusing these with the will of God, and to be able to resist them when justice is at risk of compromise. Similarly, we need to be willing to put our own motives and agendas under 
scrutiny, so as to ensure, so far as is possible, that our deliberations are carried out with integrity and a genuine desire to further the interests of God's kingdom rather than our own.

\section{Bibliography}

Anstey RT (1975) The Atlantic Slave Trade and British Abolition 1760-1810. London: Macmillan.

Bales K (2007) How We Will End Slavery in the Twenty-First Century. In Smith D (ed) Slavery Now and Then. Eastbourne: Kingsway.

Barnes A (1857) An Inquiry into the Scriptural Views of Slavery. Philadelphia, PA: Parry \& McMillan.

Brueggemann W (1997) Theology of the Old Testament: Testimony, Dispute, Advocacy. Minneapolis, MN: Fortess.

Callahan AD (2006) The Talking Book. New Haven, CT: Yale University Press.

Carretta V (2004) Unchained Voices: an Anthology of Black Authors in the English Speaking World of the 18th Century. Lexington, KY: The University Press of Kentucky.

Carson MLS (2016) Human Trafficking the Bible and the Church: An Interdisciplinary Study. Eugene, OR: Cascade.

Cuguano CO (1787) Thoughts and Sentiments on the Evil and Wicked Traffic of the Slavery and Commerce of the Human Species (London 1787). Reprinted in Carretta V, ed (1996) Unchained Voices: an Anthology of Black Authors in the English Speaking World of the 18th Century. Lexington, KY: The University Press of Kentucky, pp. 145-84.

Davidson GST (2009) Coleridge. In Lemon R et al., ed (2009) The Blackwell Companion to the Bible in English Literature. Oxford: Blackwell.

Davis DB (1970) The Problem of Slavery in Western Culture. Harmondsworth: Penguin.

Durham G (2010) The Spirit of the Quakers. New Haven and London: Yale University Press.

Elliott EN, ed (1860) Cotton is King, And Pro-slavery Arguments. Augusta: Pritchard, Abbott and Loomis.

Equiano O (2003) The Interesting Narrative and Other Writings, first published 1781. London: Penguin.

Fiorenza ES (1999) Rhetoric and Ethic: The Politics of Biblical Studies. Minneapolis, MN: Fortress.

Fox-Genovese E, Genovese ED (2005) The Mind of the Master Class: History and Faith in the Southern Slaveholders' Worldview. New York, NY: Cambridge University Press. 
Frost JW (1980) The Quaker Origins of Antislavery. Norwood, PA: Norwood Editions.

Harding V (1997) Religion and Resistance among Antebellum Slaves 18001860. In Fulop TE and Raboteau AJ (eds) African-American Religion: Interpretive essays in History and Culture. New York, NY: Routledge, pp. 107129.

Kenrick FP (1981) The Acts of the Apostles, the Epistles of Saint Paul, the Catholic Epistles and the Apocalypse. New York, NY: n.p.

Kolchin P (1983) American Slavery 1619-1877. London: Penguin.

Maxwell JF (1975) Slavery and the Catholic Church: the History of Catholic Teaching Concerning the Moral Legitimacy of the Institution of Slavery. London: Barry Rose.

Meeks WA (1996) The 'Haustafeln' and American Slavery: A Hermeneutical Challenge. In Lovering E and Sumney JA (ed) Theology and Ethics in Paul and His Interpreters. Nashville, TN: Abingdon, pp 232-253.

Morgan K (2005) Slavery in America: A Reader and Guide. Edinburgh: Edinburgh University Press.

Noll MA (1983) The Princeton Theology 1812-1921: Scripture, Science and Theological Method from Archibald Alexander to Benjamin Breckenridge Warfield. Grand Rapids, MI: Baker Book House.

Noll MA (2006) The Civil War as a Theological Crisis. Chapel Hill, NC: University of North Carolina Press.

Raboteau AJ (2004) Slave Religion: the 'Invisible Institution' in the Antebellum South. Updated edition. Oxford: Oxford University Press.

Reventlow HG (1984) The Authority of the Bible and the Rise of the Modern World. London: SCM.

Rice MH (1964) American Catholic Opinion in the Slavery Controversy. Gloucester, MA: Peter Smith.

Ross FA (1969) Slavery Ordained of God, first published 1857. Miami, FL: Mnemosyne Publishing.

Ruston R (2004) Human Rights and the Image of God. London: SCM.

Saillant J (2000) Origins of African American Hermeneutics in EighteenthCentury Black Opposition to the Slave Trade and Slavery. In Wimbush VL (ed) African Americans and the Bible. New York, NY: Continuum, pp. 236-250.

Smith MM (1998) Debating Slavery: Economy and Society in the Antebellum American South. Cambridge: Cambridge University Press.

Soderlund JR (1985) Quakers and Slavery: a Divided Spirit. Princeton, NJ: Princeton University Press.

Stowe HB (1995) Uncle Tom's Cabin, first published 1852. Ware: Wordsworth Editions. 
Thiselton AC (2009) Hermeneutics: an Introduction. Grand Rapids, MI: Eerdmans.

Thomas JL, ed (1965) Slavery Attacked: the Abolitionist Crusade. Englewood Cliffs, NJ: Prentice-Hall.

Torbett D (2006) Theology and Slavery: Charles Hodge and Horace Bushnell. Macon, GA: Mercer University Press.

Webster J (2003) Holy Scripture: a Dogmatic Sketch. Cambridge: Cambridge University Press. 